\title{
Varicella meningoencephalitis : An atypical presentation in an immunocompetent individual with seizures
}

\author{
Uma Senthilkumar*, Jordana Cheta, Ryan Platzbecker and Paul Marik \\ Eastern Virginia Medical School. Norfolk VA, 23507, USA
}

\begin{abstract}
Viral meningitis, also known as aseptic meningitis, is the most common cause of meningitis and is responsible for between 26,000 and 42,000 hospitalizations yearly in the United States [1]. Bacterial meningitis affects about 4,000 people each year, while viral meningoencephalitis affects about 10 people in every 100,000 . The most commonly identified pathogens are enterovirus, herpes simplex virus and human immunodeficiency virus. Varicella, rabies and influenza are other viruses that are rarely responsible for viral meningitis. Varicella Zoster is a relatively common disorder in immunocompromised patients characterized by radicular pain and grouped vesicular eruptions. The typical findings in reported cases of VZV meningitis involve skin manifestations and classical signs of meningitis such as neck stiffness. However, only a few cases of meningitis caused by Varicella Zoster Virus (VZV) have been reported. The incidence of VZV meningitis in immunocompetent patients has been reported to be as low as $0.5 \%$. We report an atypical presentation of VZV meningitis in an immunocompetent 59-year-old adult male with headache, dizziness, sequalae of seizures without fever and skin manifestations.
\end{abstract}

\section{Background}

Varicella-zoster virus (VZV) is one of eight herpes viruses known to cause human infection and is distributed worldwide. VZV infection causes two clinically distinct forms of disease: primary varicella (chickenpox) and herpes zoster (shingles). Primary VZV infection often becomes latent in cranial nerve and dorsalroot ganglia (DRG), which can reactivate decades later to produce clinical manifestations [2]. VZV can become latent in DRG and when reactivated commonly causes a dermatomal, vesicular rash called shingles as well as postherpetic neuralgia. This rash is often accompanied by a prodrome of pain and itching. Less commonly, VZV reactivation can cause a wide spectrum of neurologic disease including meningitis, encephalitis, ophthalmoplegia, cranial nerve dysfunction, and cerebral vasculopathies that can result in TIAs and stroke like syndromes. Reactivation becomes more likely in individuals who are immunocompromised and in the elderly as cellmediated immunity fades [3]. The typical findings in reported cases of VZV meningitis involve skin manifestations and classical signs of meningitis such as neck stiffness [4].

Its neurologic manifestations are often indistinguishable from other viral and bacterial meningoencephalitis. VZV, however, typically presents with its classic vesicular rash, which usually clues clinicians onto the diagnosis. Patients presenting without such a typical rash and prodrome pose a diagnostic dilemma. Basic cerebral spinal fluid (CSF) findings consistent with VZV meningitis are typically indistinguishable from other viral etiologies. Those can often include cell count with $>50 \%$ lymphocytes, low protein concentrations (usually less than $300 \mathrm{mg} / \mathrm{dl}$ ), normal glucose concentrations, and a negative gram stain and culture [5]. CSF pleocytosis seems to be commonly present in VZV meningitis [6].

Diagnosis requires identification of VZV DNA in the CSF or serum, typically using PCR amplification, which has become increasingly available as a rapid diagnostic tool $[7,8]$. In addition to its increasing availability, it has been shown to be both sensitive and specific for the detection of VZV in CSF, particularly in comparison to VZV culture $[9,10]$. Most viral pathogens affecting the central nervous system (CNS) initially infect mucosal surfaces of the respiratory and gastrointestinal tract, followed by viral replication in regional lymph nodes. This precedes a primary viremia that signals the onset of illness and subsequent seeding of other organs.

Except for neonatal herpes simplex virus infections (HSV), most viruses reach the CNS during a second viremia that follows viral replication in other organs, particularly the liver and spleen [11]. The mechanisms involved in viral transport from the circulation to the brain are not clearly understood. However, it is clear that transendothelial passage of the virus occurs in vessels of the choroid plexus, meninges, or cerebrum by one or more of the following mechanisms: Bridging the endothelium within migrating leukocytes; Pinocytosis or colloidal transport ; Breaking through damaged endothelium; Direct infection of endothelial cells [11].

VZV can cause radicular pain in the absence of skin lesions and without presence of CSF pleocytosis or documented CNS infection with VZV by PCR; such cases are referred to as zoster sine herpete. There are rare cases of meningitis caused by VZV. VZV meningitis usually has a mild course, but serious complications have been reported. Patients present with headache and usually fever. Nuchal rigidity and meningeal irritation are not always present [12].

*Correspondence to: Uma Senthilkumar, Department-Internal Medicine, Eastern Virginia Medical School. Norfolk VA, 23507, USA, Tel: 757-446-8910; E-mail: umasenya@gmail.com

Key words: Varicella meningitis, VZV, aseptic meningitis, viral meningitis, meningitis seizures, immunocompetent meningitis

Received: September 10, 2018; Accepted: September 20, 2018; Published: September 24, 2018 
In our literature search we found only one case where focal seizures were noted in which the patient had typical presentation with rash [6].

\section{Case}

Our patient is a 59-year-old African American male who presented with worsening dizziness, confusion, ataxia, lethargy and left-sided frontal headache. He denied nausea, vomiting, vision problems, fever, chills, diarrhea, chest pain, shortness of breath or sick contacts. Patient stated symptoms started after he inhaled Terro ant spray. He had presented to the emergency room 5 days prior, was told that his laboratory and computed tomography (CT) of the head was negative and was discharged on Azithromycin for sinusitis. Upon hospital admission this time, as patient was receiving his second head CT, he began to have a tonic-clonic seizure, which was subdued with $4 \mathrm{mg}$ of Ativan. He was intubated and transferred to the intensive care unit. Upon ICU arrival he went into another generalized tonic-clonic seizure and was placed on propofol, midazolam, and phenytoin drip before he was seizure free on electroencephalography (EEG).

Past medical history was significant for hypothyroidism, poorly controlled type 2 diabetes mellitus and hepatitis C treated with Harvoni. Prior to his seizure on admission physical exam was remarkable for lethargy and gait instability (ataxic heel to toe) and exam was unremarkable for rashes, cardiac murmurs, nuchal rigidity, photophobia or romberg's sign. Vital signs on admission were normal. Complete blood count, basic metabolic panel, liver function tests, thyroid function tests were all unremarkable. Cerebral spinal fluid (CSF) results revealed an opening pressure $29 \mathrm{~mm}$ water, WBC 682/ CUMM, red blood cell 1000/CUMM, neutrophils $1 \%$, lymphocytes $94 \%$, monocytes 5\%, glucose $63 \mathrm{mg} / \mathrm{dL}$, protein $287 \mathrm{mg} / \mathrm{dL}$ and negative gram stain. Viral cultures were pending. The patient was started on broad-spectrum antibiotics and acyclovir for possible meningitis. Echocardiogram showed mild left ventricular hypertrophy. Computed tomography of the head reveled no acute intracranial pathology.

Magnetic resonance imaging revealed mild to moderate burden of white matter abnormality, nonspecific but most likely due to chronic microvascular ischemic disease. No acute stroke. The next day sedation was weaned off and patient remained seizure free on continuous EEG and was extubated 3 days later the CSF came back positive for an elevated Varicella PCR of 42016. Patient was seen by infectious diseases consultant and was advised a course of acyclovir $10 \mathrm{mg} / \mathrm{kg}$ intravenous every 8 hours for 14 days. All other antibiotics were stopped. Upon discharge, the patient had fully recovered from his symptoms with no neurologic sequalae.

\section{Discussion}

This unique case illustrates an atypical presentation of VZV meningoencephalitis in an immunocompetent patient that lacks many of the obvious features that usually distinguish the disease. Our patient lacked the vesicular rash, as well as other typical features of aseptic meningitis including nuchal rigidity, headache, photophobia, etc. Additionally, the patient's course was complicated by seizure, another relatively uncommon feature of VZV meningoencephalitis. VZV infection or reactivation is, rightfully, most commonly associated with the vesicular rash and prodromal pain that usually accompanies it. There is however a significant amount of literature and a number of case reports that also support the existence of a VZV entity called Zoster Sine Herpete, or VZV without rash. Indeed, VZV has also been shown to cause vasculitis, myelopathy, and other syndromes without rash $[8,9]$. It also more rarely presents with the neurologic manifestations previously discussed in the absence of rash. There are few case reports documenting this, even fewer in immunocompetent patients [4,5,7]. The incidence of VZV meningoencephalitis in immunocompetent patients has been reported to be as low as $0.5 \%$ [13].

Our literature search revealed 9 previous case reports of VZV meningitis in immunocompetent individuals (Table 1). A case series from Becerra, et al. in 2012 included seven such patients. Of these seven, everyone presented with headache, four with fever, four with rash, two with neck stiffness, and one with photophobia. None presented with seizure or ataxia. Other reports, including Sanguanko in 2015, had a patient present with facial pain, rash, and photophobia; Habib, et al. in 2009 included a patient presenting with headache, photophobia, and nausea/vomiting; Pasedag in 2014 presented a patient with headache and nausea/vomiting; and finally, Klein in 2010 presented a patient with headache, nausea, photophobia, and myalgias [6,7,14-16]. The variety of presentations in these cases, in addition to that of our patient clearly indicate that a high index of suspicion is necessary to diagnose this disease.

Though our patient's presentation was atypical, given the variety of other VZV syndromes that can present without rash, it is therefore not entirely surprising that its neurologic manifestations might also present in this way. Indeed, it is possible or even probable that VZV

Table 1. lists all previous cases with VZV meningitis without rash in immunocompetent older patients [6,7,14-16]

\begin{tabular}{|c|c|c|c|c|c|c|c|}
\hline Case & Age/gender & Clinical manisfestation & Brain imaging & CSF findings & & & \\
\hline & & & & Glucose (mg/dL) & PCR (mg/L) & WBC $\times 106$ & Protein $(\mathrm{mg} / \mathrm{dL})$ \\
\hline Our case 2017 & $59 \mathrm{M}$ & $\begin{array}{l}\text { Headache, altered mental status, } \\
\text { ataxia, seizure }\end{array}$ & MRI normal & & 42016 & 682 & 287 \\
\hline Sanguankeo [7] & $51 \mathrm{M}$ & $\begin{array}{l}\text { painful papular rash on forehead, } \\
\text { unilateral neck and facial pain, } \\
\text { photophobia, headache, fever, } \\
\text { vomitting }\end{array}$ & CT neg & 45 & + & 532 & 130 \\
\hline Pasedag [15] & $18 \mathrm{M}$ & Headache, nausea, vomitting & MRI normal & 42 & 50000 & 1720 & 146 \\
\hline \multirow[t]{5}{*}{ Becerra 2013case series [6] } & $48 \mathrm{~F}$ & Headache, fever, rash & & & 0 & 237 & 740 \\
\hline & $36 \mathrm{M}$ & Headache & & & 2 & 1157 & 218 \\
\hline & $28 \mathrm{M}$ & Headache, fever, neck stiffness & & & 0 & 120 & 730 \\
\hline & $27 \mathrm{M}$ & Headache, fever, rash & & & 0 & 403 & 129 \\
\hline & $49 \mathrm{M}$ & Headache, fever, rash & & & 3 & 82 & 600 \\
\hline Klein [16] & $53 \mathrm{~F}$ & Headache, nausea, photophobia & & CT mild atrophy & 0 & 923 & 165 \\
\hline Habib [14] & $26 \mathrm{~F}$ & $\begin{array}{l}\text { Headache, nausea, vomitting, } \\
\text { photophobia }\end{array}$ & & 28 & 127000 & 331 & 219 \\
\hline
\end{tabular}


meningitis and particularly VZV meningitis without rash may be more prevalent than current literature suggests. Indeed, several studies have suggested VZV may represent up to $29 \%$ of aseptic meningitis, though others suggest this may be much lower [17].

As mentioned, CSF findings of VZV are typically indistinguishable from other viral etiologies. Therefore VZV DNA PCR is typically required for diagnosis, particularly in the absence of rash or other diagnostic clues. A high degree of clinical suspicion for VZV should be had in the setting of aseptic meningitis without other obvious cause, as the sequelae as we have shown can be quite serious. It has been estimated that up to $50 \%$ of individuals with VZV neurologic symptoms may have persistent symptoms up to 3 months following treatment [10]. Patients presenting with neurologic manifestations of aseptic meningitis should receive empiric intravenous acyclovir. Because the syndromes of viral meningitis and encephalitis often overlap with those of their bacterial counterparts, empiric anti-bacterial are also usually warranted until the diagnosis is clear [18].

For these reasons, VZV should be kept within the differential for patients presenting either typically or atypically with aseptic meningitis. It is imperative that lumbar puncture and CSF studies including VZV PCR not be delayed.

\section{References}

1. Rotbart HA (2000) Viral Meningitis: Epidemiology, pathogenesis and etiology in children. Semen Neurol 20: 277.

2. Logan SA, MacMahon E (2008) Viral meningitis. BMJ 336: 36-40. [Crossref]

3. Gilden D, Cohrs RJ, Mahalingam R, Nagel MA (2010) Neurological disease produced by varicella zoster virus reactivation without rash. InVaricella-zoster Virus. Springer, Berlin, Heidelberg. pp. 243-253.

4. Goyal H, Thakkar N, Bagheri F, Srivastava S (2013) Herpes zoster meningitis with multidermatomal rash in an immunocompetent patient. Am J Emerg Med 31: 1622$1622 \mathrm{e} 1$.
5. Whitley RJ, Cobbs CG, Alford CA, Soong SJ, Hirsch MS, et al. (1989) Diseases that mimic herpes simplex encephalitis: diagnosis, presentation, and outcome. JAMA 262: 234-239.

6. Becerra JC, Sieber R, Martinetti G, Costa ST, Meylan P, et al. (2013) Infection of the central nervous system caused by varicella zoster virus reactivation: a retrospective case series study. Int J Infect Dis 17: e529-534.

7. Sanguankeo A, Upala S, Sornprom S, Thamcharoen N (2015) Varicella-zoster meningitis with a late-onset of skin eruption. BMJ Case Rep 2015. [Crossref]

8. Bergström T (1996) Polymerase chain reaction for diagnosis of varicella zoster virus central nervous system infections without skin manifestations. Scand J Infect Dis Suppl 100: 41-45. [Crossref]

9. DeBiasi RL, Tyler KL (2004) Molecular Methods for Diagnosis of Viral Encephalitis Clin Microbiol Rev 17: 903-925.

10. Corral I, Quereda C, Antela A, Pintado V, Casado JL, et al. (2003) Neurological complications of varicella-zoster virus in human immunodeficiency virus-infected patients: changes in prevalence and diagnostic utility of polymerase chain reaction in cerebrospinal fluid. J Neurovirol 9: 129-135.

11. Cassady K, Gnann JW, Whitley RJ (2003) Viral infections of the central nervous system. In: Therapy of Infectious Diseases, Baddour L, Gorbach S (Eds), WB Saunders, Philadelphia. pp: 237.

12. Weerkamp NJ, Keizer K, Boel CH, de Rijk MC (2010) Meningoencephalitis caused by varicella zoster virus. Ned Tijdschr Geneeskd 154: A1575. [Crossref]

13. Cohen JI, Brunell PA, Straus SE, Krause PR (1999) Recent advances in varicella-zoster virus infection. Ann Intern Med 130: 922-932. [Crossref]

14. Habib AA, Gilden D, Schmid DS, Safdieh JE (2009) Varicella zoster virus meningitis with hypoglycorrhachia in the absence of rash in an immunocompetent woman. $J$ Neurovirol 15: 206-208. [Crossref]

15. Pasedag T, Weissenborn K, Wurster U, Ganzenmueller T, Stangel M, et al. (2014) Varicella zoster virus meningitis in a young immunocompetent adult without rash: a misleading clinical presentation. Case Rep Neurol Med 2014: 686218.

16. Klein NC, McDermott B, Cunha BA (2010) Varicella-zoster virus meningoencephalitis in an immunocompetent patient without a rash. Scand J Infect Dis 42: 631-633.

17. Pollak L, Dovrat S, Book M, Mendelson E, Weinberger M (2012) Varicella zoster vs. herpes simplex meningoencephalitis in the PCR era. A single center study. $J$ Neurol Sci 314: 29-36. [Crossref]

18. Tunkel AR (2016) Aseptic meningitis in adults. In: UpToDate, Post, TW (Ed), UpToDate, Waltham, MA.

Copyright: (C)2018 Senthilkumar U. This is an open-access article distributed under the terms of the Creative Commons Attribution License, which permits unrestricted use, distribution, and reproduction in any medium, provided the original author and source are credited. 